\title{
9. All That Glitters: Betting markets and the 2013 Australian federal election
}

\author{
Simon Jackman
}

Political betting markets featured prominently in pre-election prognostication, perhaps more so ahead of the 2013 election than in any other recent Australian election. Major newspapers such as the Australian and the Australian Financial Review frequently reported on the state of the national betting markets, offering daily updates after the election date was announced. I routinely referenced the betting markets in weekly columns I was penning for the Guardian Australia. ${ }^{1}$

The attention garnered by political betting markets is a relatively recent development. To be sure, political betting has been around for a long time in Australia; the survey by Rhode and Strumpf (2013) cites evidence of person-toperson wagering on colonial elections through to newspaper reports of relatively large wagers being placed on the 1949 federal election. This is despite the fact that gambling on federal elections has been illegal for most of the history of the Commonwealth. 'Wagering on the result of any election' remained on the list of electoral offences ${ }^{2}$ until extensive amendments were made to the Commonwealth Electoral Act in 1983.

Political betting has since come out of the shadows. The rise of online bookmaking is a large part of the story, increasing the accessibility and visibility of political betting markets (and many other betting markets), relative to pre-internet forms of wagering.

Not coincidentally, the intellectual respectability of political betting markets has grown in recent decades, reflecting a broader interest in prediction markets as forecasting tools in a wide array of domains; see, for example, the survey in Wolfers and Zitzewitz (2004). In election betting markets, wagers are being placed over discrete events. For instance, which party will form government after the election, or which party or candidate will win a particular House of Representatives seat. Under the assumption that the markets are efficient,

1 For example, Jackman 2013a.

2 For example, section 182, Commonwealth Electoral Act 1902; section 170, Commonwealth Electoral Act, 1918. 
market-clearing prices reflect an aggregation of the probabilities agents assign to these discrete events; information that changes agents' probabilistic beliefs is reflected in price movements (see, e.g. Wolfers and Zitzewitz 2006).

The consensus among social scientists, political commentators and the public is that political betting markets produce reasonably accurate forecasts of election outcomes. In the specific case of Australian elections, Wolfers and Leigh (2002) made a persuasive case for the predictive power of political betting markets, contrasting the predictions of: (1) opinion polls; (2) statistical models analysing the long-run relationship between macro-economic conditions and election outcomes; and (3) the prices offered by the betting markets ahead of the 2001 federal election. Leigh and Wolfers (2006) considered predictions of the 2004 federal election, concluding that national polls varied too much - both across polling houses and over time - to be 'particularly useful' as forecasts, or at least relative to the 'useful' forecasting performance and 'more reasonable' degree of volatility exhibited by political betting markets.

Critics contend that while betting markets may produce good forecasts of election outcomes, this is largely because they are reacting to the polls. In this view, the predictive power of the betting markets is due to the fact that they incorporate the information in polls. Indeed, the polls are not nearly as poor a predictor of election outcomes as Leigh and Wolfers might have us believe, at least not when aggregated across survey/polling houses, temporally smoothed, and when corrections for house effects are applied; see, for instance, my pollaveraging model (Jackman 2005; Jackman 2009: Chapter 9) and the work of other poll-aggregators such as William Bowe. ${ }^{3}$

It is worth noting that in their 2006 paper, Leigh and Wolfers did not suggest nor demonstrate that the betting markets ignored the polls. Although they did not explicitly test that betting markets react nearly instantaneously to changes in the polls, Leigh and Wolfers found no lag in the reaction of the 2004 Betfair market to changes in the polls ${ }^{4}$ - inviting the conclusion that the Betfair market reacted nearly instantaneously - and that the Centrebet market adjusted to polling information with a slight delay (2006: 332 Panel D, Table 3). Leigh and Wolfers also pointed to the rapid reaction of the betting markets to important campaign events in 2004 (2006: 331, Figure 2). On the other hand, Leigh and Wolfers do imply that the polls have a limited effect on the betting markets. If we are to accept their conclusion that betting markets provide 'useful' forecasts of election outcomes, but that polls are not 'particularly useful', then the betting markets must be reasonably independent of the polls.

3 Bowe publishes his model at the popular blog Pollbludger, hosted by Crikey!: <www.crikey.com.au>.

4 Changes in the Betfair prices appear to be linearly independent of these lagged changes in the polls, where 'recent' is defined as changes in the polls between one and eight days ago, two and nine days ago, and three to 10 days ago. Therefore, any reaction in the Betfair market to the polls happens instantaneously or with a longer lag. 
Whatever one's view of the efficient markets hypothesis (the assumption that markets process relevant information efficiently), it seems implausible that betting markets would ignore polling information or that polls are of no forecasting value whatsoever. It further seems implausible that today's betting prices always anticipate tomorrow's poll results. Poll results may contain new information. It would be astonishing if markets failed to react to that information. Accordingly, it isn't especially interesting to ask if the betting markets react to the polls, but how much and under what conditions.

\section{The national 'party to form government' betting market, 2011-13}

Starting on 1 July 2011, I gathered data on the prices in the election betting market offered by two of Australia's largest online internet bookmakers, Centrebet and Sportsbet. Prices were offered on the 'party to form government' after the next election: Labor or the Coalition. I used computer programs to store the prices offered on the websites of these bookmakers every hour. There is a small amount of missing data due to occasional computer and/or network outages, as well as some brief periods of political drama when bookmakers took their markets offline. ${ }^{5}$ The resulting hourly time series commences at $5 \mathrm{pm}, 1$ July 2011 (for Centrebet; at 6 pm, 5 July 2011 for Sportsbet) and ceases at 9 pm on election night, 7 September 2013, Sydney time.

Both Centrebet and Sportsbet quote decimal odds, the value of a successful onedollar wager, bounded from below at 1.0. Higher-priced wagers reflect beliefs that the corresponding event is less likely to occur. It is straightforward to convert the price offered for a particular outcome into the implied probability of the event occurring. If event $A$ is priced at $p$ and event $\sim A$ at $q(p, q>1)$, then the implied probability of event $A$ occurring is $(1 / p) /(1 / p+1 / q)$. For instance, wagers on flips of fair coins (e.g. the coin toss ahead of a cricket match) are often priced at about 1.95 even though 2.00 would seem the fair price of a 50-50 proposition. Note that $1 / 1.95+1 / 1.95>1$, with the excess over one the source of the bookmaker's profit (the 'over-round' or 'vigorish'). Accordingly, the inverse prices $(1 / p, 1 / q$ etc) cannot be considered probabilities until divided by the sum of the inverse prices, ensuring that the resulting implied probabilities sum to one over the set of outcomes, effectively factoring out the bookmaker's profit.

\footnotetext{
5 Of the possible 19,181 hourly observations over this period, I have 18,754 hourly observations from Centrebet (2.2 per cent missing) and 17,990 hourly observations from Sportsbet (6.2 per cent missing). The longest sequence of missing data in the Centrebet series is a one-week gap in October 2011; I am also missing Sportsbet data for the same period. For the Sportsbet data the longest span of missing data is between 23 February 2013 and 21 March 2013. These gaps in the data series seem to pose no threat to the validity of the analyses presented below.
} 
I convert the quoted prices to an implied probability of a Labor win (henceforth 'IPW'), which I multiply by 100 for convenience of presentation. For instance, through June 2012, Sportsbet offered prices of 7.00 on a Labor win and 1.10 on a Coalition win, implying a $(1 / 7) /(1 / 7+1 / 1.1)=13.5$ per cent probability of a Labor win.

Figure 1 displays the hourly time series of ALP IPWs from Centrebet and Sportsbet, from 1 July 2011 to the 2013 election. The two markets generally track together, with Centrebet's prices exhibiting more volatility than Sportsbet. At no point over the 26 months spanned by these data did market prices reflect a belief that Labor was more likely to win the election than the Coalition. The shortest Labor price and longest Coalition price in these data occurs at the very start of the series. On 5 July 2011, Sportsbet was offering Labor at 2.55 and the Coalition at 1.50, corresponding to a 37 per cent IPW. Labor's price generally eased over the remainder of the term, save for some recoveries in late 2011 and late 2012 and in the immediate aftermath of Rudd's return to the leadership in 2013. Considerable volatility is apparent on the afternoon of 21 March 2013, when it was widely believed that Rudd would challenge for the Labor leadership (he did not); Labor's IPW (using Centrebet's prices) jumped from 19.6 per cent to 26 per cent before returning to 19.6 per cent and falling to 15 per cent by the evening of 22 March 2013.

Rudd's eventual return on 26 June 2013 saw Labor's IPW jump from 15.5 per cent (Centrebet) and 13.3 per cent (Sportsbet) at $1 \mathrm{pm}$ that afternoon to 21.3 per cent at 8 pm (Centrebet) and 20.8 per cent at 6 pm (Sportsbet). Labor's price recovered further in the weeks ahead, reaching 2013 peaks with ALP IPWs of 34.9 per cent and 33.1 per cent at Centrebet and Sportsbet, respectively, on 16 July 2013. Election betting firmly favoured the Coalition throughout August 2013. Labor's price blew out at both betting agencies over the campaign proper, with Sportsbet paying out its Coalition wagers on 29 August 2013, nine days ahead of the election. ${ }^{6}$ By 1 September, Labor was at 16 to the Coalition's 1.01 at Centrebet (IPW of 5.9 per cent) and 12.50 to 1.02 (IPW of 7.5 per cent) at Sportsbet. Centrebet's market closed as the polls opened on election day, with Labor at 14.00 to the Coalition's 1.02 (6.7 per cent IPW). Sportsbet kept its market open throughout election day, with Labor's price easing from 12.00 to 41.00 and the IPW falling from 7.9 per cent to 2.4 per cent.

In short, the Coalition was always firm favourite to win the 2013 election. In this sense the betting markets 'got it right' and well ahead of the election.

6 Maher (2013). The announcement by Sportsbet appears at: <http://www.Sportsbet.com.au/blog/ home/Sportsbet-pays-out-early-on-coalition-to-win-2013-election>. 


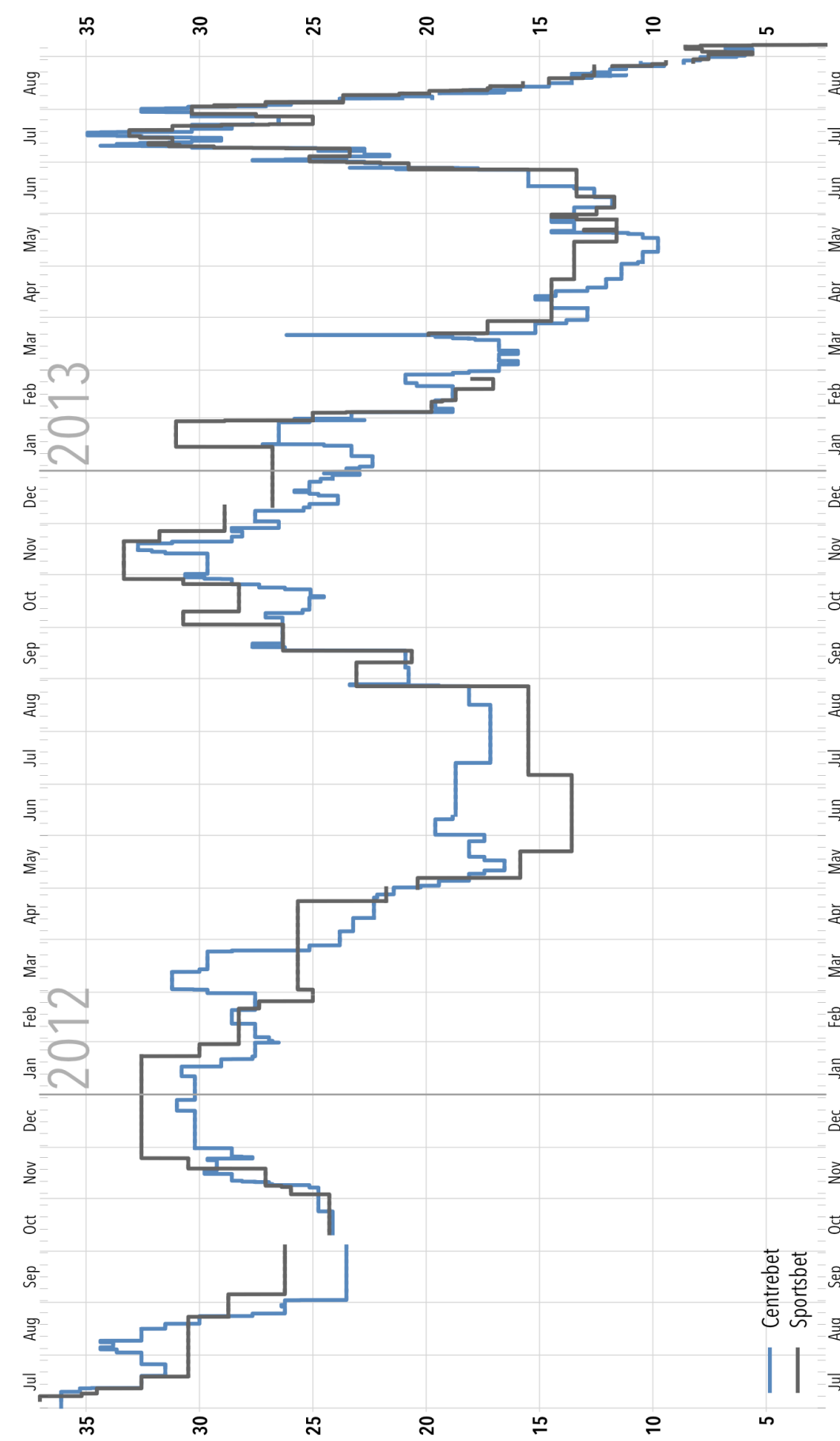

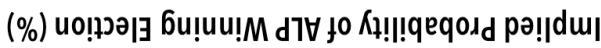




\section{Large betting market movements coincide with polling 'news'}

I also gathered data on national opinion polls fielded in the 2010-13 parliamentary term. I recorded poll results, sample sizes and field dates, but also the 'release date' of each poll, the date at which the poll's results were published or otherwise released to the public and thus the earliest time at which we might expect to see any reaction to the polling information in the betting markets.

Figure 2 displays the eight largest daily changes $^{7}$ in the betting markets in descending order of magnitude. Each panel shows the trajectory of ALP IPW over a 72-hour period bracketing a day of especially large market movement. To the right of each panel I note recent polling information (changes in major polls' estimates of Labor's share of two-party-preferred voting intentions, henceforth ALP TPP) or political events coinciding with or immediately preceding the corresponding time period. As noted earlier, election day itself saw a large movement in IPW at Sportsbet - the largest in any 24-hour period in my databut is excluded from this set of 'largest daily changes'.

These data clearly indicate that the markets are responding to the polls. Putting election day aside, the single biggest movement in IPW occurred on Tuesday, 9 July 2013. That day the Australian published a Newspoll result of ALP TPP at 50 per cent, up from 49 per cent in the Newspoll published the previous week; the poll also showed Rudd vastly outperforming Abbott as 'preferred prime minister'. This was Labor's best Newspoll result since October 2012 and further confirmed the recovery in Labor's poll numbers following Rudd's return. Social media reported the result late on Monday evening, 8 July, and the Newspoll result dominated Tuesday's political news. Both Centrebet and Sportsbet swung towards Labor overnight and through the day: Labor's price moved from 4.15 to 3.10 at Centrebet (the ALP IPW moving from 22.7 per cent to 30.3 per cent) and from 4.00 to 3.20 at Sportsbet (23.3 per cent to 29.4 per cent). Labor's gains continued the next day, if less dramatically: Labor reached 2.75 at Centrebet and ended the day at 2.80 (33.6 per cent), and reached 3.00 at Sportsbet (31.4 per cent).

7 I group the hourly data into $9 \mathrm{pm}$ to $9 \mathrm{pm}, 24$-hour periods (Sydney time), since newspaper websites, other media (e.g. the ABC's Lateline) and social media often disseminate poll results late in the evening prior to their 'official' release. 


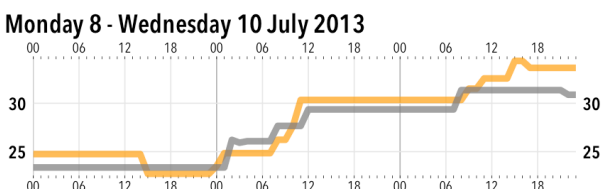

Sunday 26 - Tuesday 28 August 2012

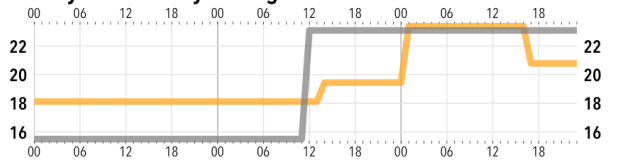

Tuesday 25 - Thursday 27 June 2013

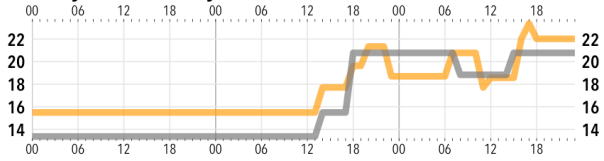

Wednesday 20 - Friday 22 March 2013

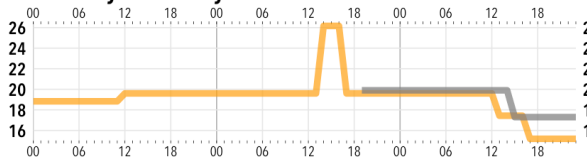

Tuesday 29 - Thursday 31 January 2013

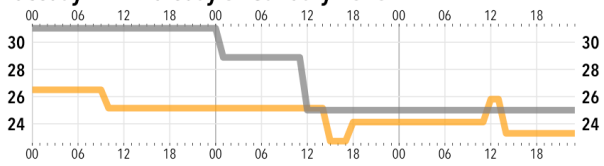

Events: Gillard announces intention to hold election on Sept 142013

Recent Polls: Morgan 48 to 49.5

Essential 46 to 46

Sunday 16 - Tuesday 18 September 2012

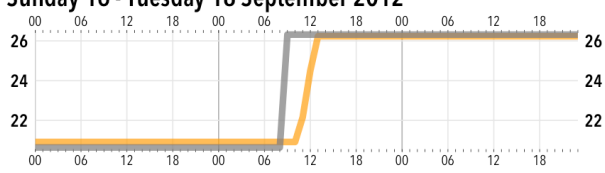

Recent Polls: Newspoll 45 to 50

Nielsen 46 to 47

Essential 46.5 to 46.5

Morgan 46.5 to 46.5

Sunday 3 - Tuesday 5 February 2013

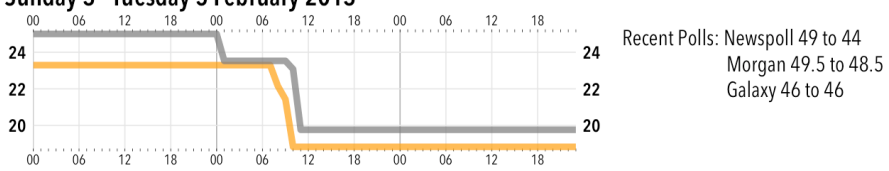

Monday 22 - Wednesday 24 July 2013

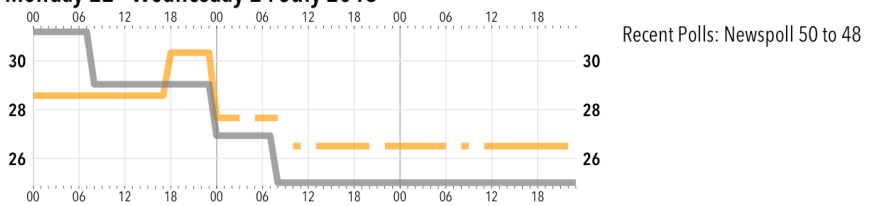

Figure 2: Eight largest daily movements in the political betting markets. Breaks correspond to periods of missing data.

Note: Each panel shows a 72-hour history of ALP IPW at Centrebet and Sportsbet, bracketing a 24-hour period of large movement. Text to the right of each panel lists recent poll movements or political events. 
Political events might have had something to do with this large movement. The biggest political news of Monday 8 July was the announcement of proposed changes to Labor's leadership selection procedures (see PM 2013). Around the same time, mainstream media reported that Abbott had repaid the Commonwealth in 2010 for 'incorrectly claimed travel expenses'; Abbott's handling of questions about the revelations on Tuesday 9 July became part of the story (Jabour 2013; Black 2013; Wilson 2013). ${ }^{8}$ Newspoll was not the only big political story on 9 July, but it largely trumped the travel expenses revelations and the ALP's proposed rule changes, leading most reports of the 'day in politics' (see Lateline 2013).

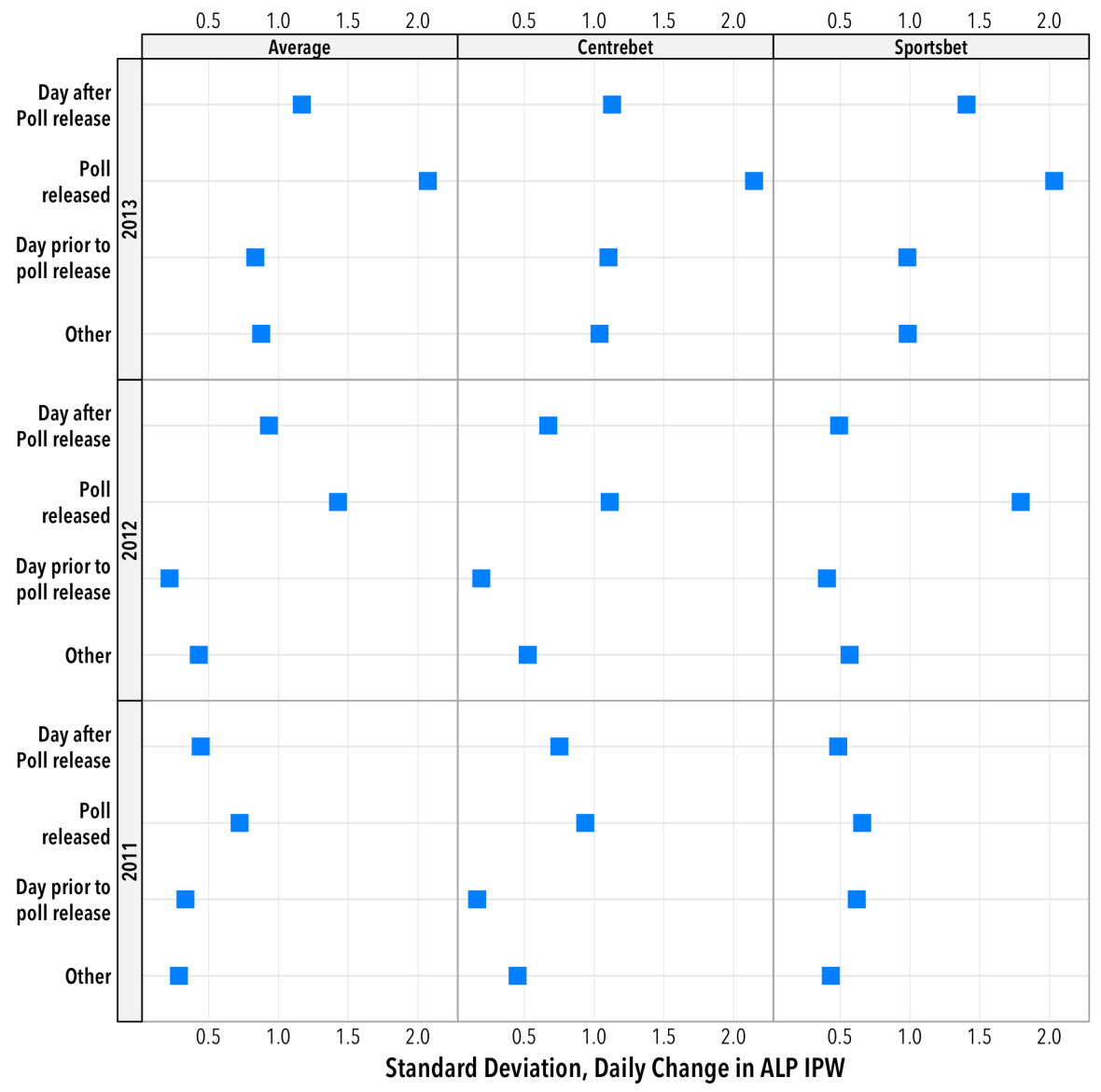

Figure 3: Standard deviation of daily change in ALP IPW, by betting agency, year and type of day

Source: Author's research. 
Political events are clearly responsible for some of the large day-on-day changes in the betting markets: Rudd's return on 26 June 2013 (third panel of Figure 2), the ALP leadership spill on 21 March 2013, in which Rudd did not nominate (fourth panel) and Gillard's 30 January 2013 announcement of her intention to hold the election on 14 September (fifth panel). The volatility in the betting market - and improvement in Labor's odds - induced by Rudd's return on 26 June continued into the next day. But polls clearly appear to be driving large market movements too, and in the anticipated directions. In addition to the substantial market movements around 9 July 2013 (first panel), seemingly due to a favourable Newspoll for Labor, poll movements appear to be the cause of the other large market changes shown in Figure 2. In each case, the polls led, or were especially prominent, in the day's political news. ${ }^{9}$ For this particular set of large day-on-day changes in the betting markets, poll movements appear to be at least as large a driver of market movements as political events.

Analysis of the complete data further suggests that betting markets are largely reacting to the polls. In Figure 3, I graph the standard deviation of the daily change in Labor's IPW by four types of day (the day after a poll release, the day of a poll release, the day before a poll release and all other days, looking at poll releases by Newspoll, Nielsen and Galaxy), subsetting the data by betting agency and year. ${ }^{10}$ There is more volatility in the betting markets on the day a poll is released - and even on the following day - than on other days. In 2013, poll releases saw movements in ALP IPW with a standard deviation of just over 2 percentage points, more than twice the volatility on days prior to a poll release or on 'other' days. Volatility in the betting markets following a poll release is more pronounced in the election year than in 2012 or 2011. The differences in betting market volatility by the four 'day types' displayed in the nine panels in Figure 3 are overwhelmingly statistically significant ${ }^{11}$ with the sole exception of the 2011 Sportsbet volatilities in the lower right panel $(p=0.22)$.

Regression analysis further supports these findings. I fit a model similar to that fit by Leigh and Wolfers (2006: Table 3), regressing the daily 9 pm ALP IPW on its lagged value, plus a term capturing change in the polls-on the day of a poll release, this variable is equal to the change in the poll relative to the last poll released by that survey house and equals zero on all other days.

9 On Monday, 27 August 2012 (Panel 2 of Figure 2), the Nielsen poll was the second story on the ABC's $A M$ (2012a) radio program. On Monday, 17 September 2012 (Panel 6), see $A M^{\prime}$ 's (2012b and 2012c) two lead stories on 17 September 2012. On Monday, 4 February 2013 (Panel 7), AM (2013a) led with 'Parliamentary year kicks off with Cabinet reshuffle and poor polls for Labor'. The arrival of a royal baby and asylum seeker policy pushed a polling story ('Polling boost for Rudd on boats, but dips on PM preference') to fourth slot on $A M$ on Tuesday, 23 July 2013 (bottom panel of Figure 2; see AM 2013b).

10 If, for instance, Nielsen released a poll the day after a Newspoll was released, then both days are classified as a 'poll release' day.

11 The greatest $p$ value is .02, from Fligner-Killeen tests of the null hypothesis that the variances of daily change in ALP IPW are constant across the four 'day types'; this non-parametric test is described in Conover, Johnson and Johnson (1981). 


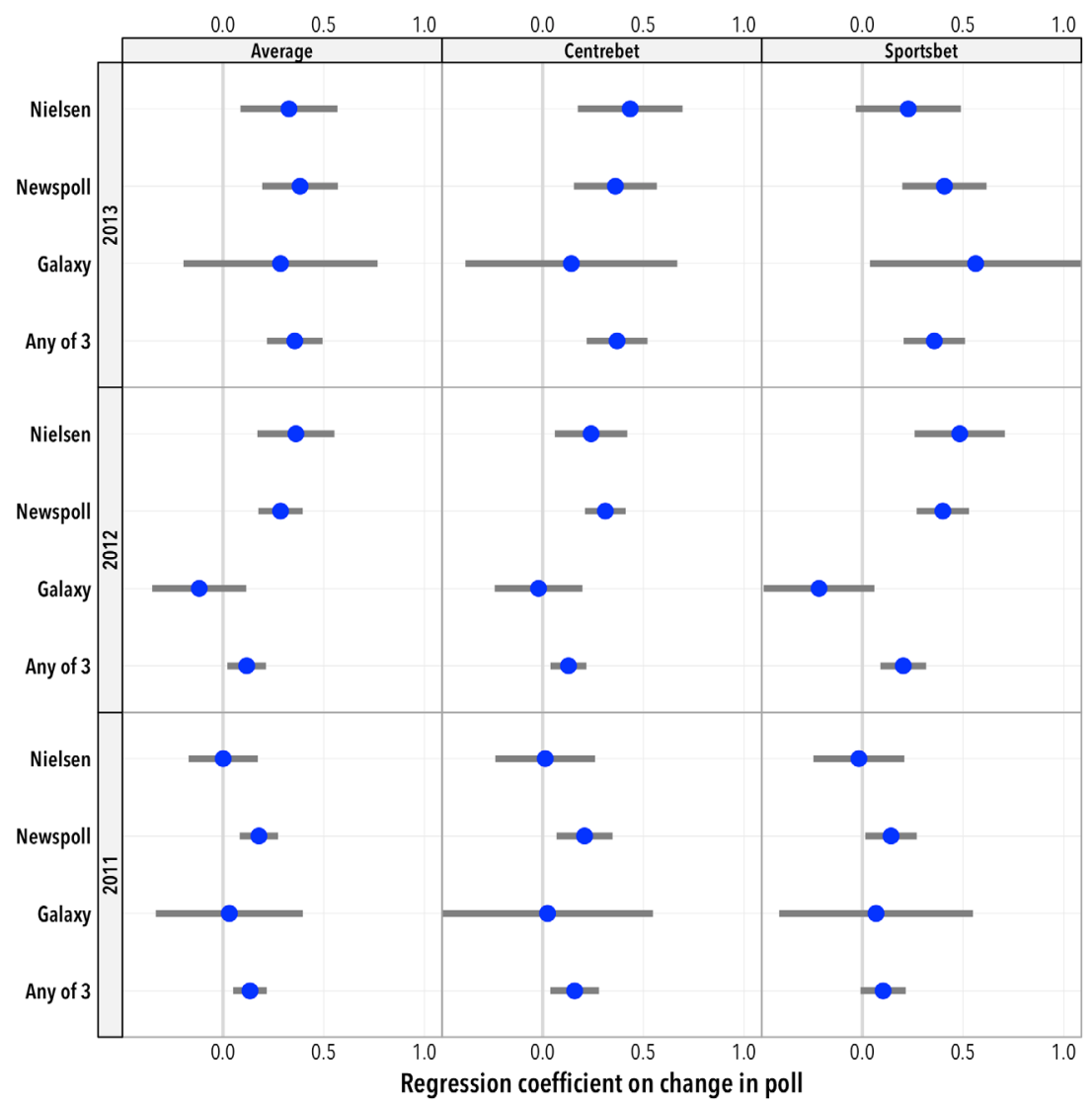

Figure 4: Regression coefficients on change in poll and 95 per cent confidence intervals, regression of daily ALP IPW on lagged ALP IPW (measured at $9 \mathrm{pm}$ Sydney time) and change in a given poll's estimate of ALP TPP, by betting agency, year and polling house

Source: Author's research.

In Figure 4, I plot the estimated coefficients of the 'poll change' variable along with 95 per cent confidence intervals, with the analysis restricted to examining the effects of changes in Newspoll, Nielsen and Galaxy (or any of the three) on Centrebet, Sportsbet and their average, in each of 2011, 2012 and 2013, producing a total of 36 regressions. The vast majority of the coefficients in Figure 4 are positive and distinguishable from zero at conventional levels of statistical significance. The responsiveness of the betting markets to the polls tends to be larger in 2013 than in earlier years. Across the nine panels in Figure 4, the Newspoll coefficient is always positive, around 0.35 to 0.40 ; that is, a 1 per cent improvement in Newspoll's estimate of ALP TPP is associated with 
a 'same day' 0.35 to 0.40 percentage point boost in ALP IPW. Coefficients with broadly similar magnitudes are obtained for Nielsen polls in 2013 and 2012. Galaxy produces fewer polls than Newspoll or Nielsen, and so the responsiveness of the betting market to this pollster is estimated with far less precision. Nonetheless it seems that a statistically significant shift in any of these polls, say, a three-point change in ALP TPP, would shock ALP IPW by about one to 1.2 percentage points.

These 'near-instantaneous' effects do not seem especially large, but keep in mind that: (a) most of the variation in ALP IPW is in a 15-point band (15 per cent to 30 per cent) in the 2011-13 period (see Figure 1); (b) ALP IPW is either a random walk or close to it (the coefficient on lagged ALP IPW is indistinguishable from one), implying that the betting markets' responses to the polls (or anything else, for that matter) are permanent; and (c) the simple regression analysis here assumes all poll changes in ALP TPP have constant effects on the betting markets irrespective of the level of ALP TPP (the effect of ALP TPP going from 43 to 44 is constrained to be the same as the effect of a change from 49 to 50) or proximity to the election. Indeed, close to the election, a series of relatively stable yet lop-sided poll results ought to produce a trend in the betting markets, which is precisely what we observe in August and September of 2013 (see Figure 1).

\section{Betting markets and poll averages}

Participants in betting markets can do better than rely on changes in a single poll. Different polls might be given different weight by different people, implying that the market is responding to an average of the polls. The markets might even be responding directly to poll averages of the sort produced by William Bowe or myself.

To investigate this possibility, I utilise the poll average I developed while writing for Guardian Australia ahead of the 2013 election. My model-based poll average estimates daily levels of ALP TPP, relying not just on Newspoll, Nielsen and Galaxy (as in the analysis above), but also incorporating national polls by Essential, Morgan, AMR, ReachTEL and Lonergan. In forming the daily poll average I treat the operative 'date' of the poll as its 'release' or 'publication' date (rather than the field dates of the poll), so as to better assess the timing of any betting market reactions to the poll. In this way the daily poll average reflects polling information released up through (and including) that particular day. Technical details appear in earlier work (Jackman 2005, 2009 and 2013a), including a discussion of how the model generates TPP estimates on days without poll releases and corrects for 'house effects' (biases specific to each polling house). 
Abbott's Gambit: The 2013 Australian Federal Election

Table 1: Regression analysis of average of Centrebet's and Sportsbet's ALP IPW, measured daily (9 pm, Sydney time), 14 January 2013 to election day ( 7 September 2013)

\begin{tabular}{|c|c|c|c|c|c|c|c|}
\hline & M1 & M2 & M3 & M4 & M5 & M6 & M7 \\
\hline Intercept & $\begin{array}{r}0.035 \\
(0.225)\end{array}$ & $\begin{array}{l}-0.034 \\
(0.210)\end{array}$ & $\begin{array}{l}-0.003 \\
(0.206)\end{array}$ & $\begin{array}{l}-0.281 \\
(0.438)\end{array}$ & $\begin{array}{r}0.070 \\
(0.200)\end{array}$ & $\begin{array}{l}-0.232 \\
(0.419)\end{array}$ & $\begin{array}{l}-0.197 \\
(0.419)\end{array}$ \\
\hline$y_{t-1}$ & $\begin{array}{r}0.992 \\
(0.012)\end{array}$ & $\begin{array}{r}0.995 \\
(0.011)\end{array}$ & $\begin{array}{r}0.993 \\
(0.011)\end{array}$ & $\begin{array}{r}1.00 \\
(0.015)\end{array}$ & $\begin{array}{r}0.989 \\
(0.010)\end{array}$ & $\begin{array}{r}0.997 \\
(0.014)\end{array}$ & $\begin{array}{r}0.996 \\
(0.014)\end{array}$ \\
\hline$\Delta$ Polls $_{\mathrm{t}}$ & & & $\begin{array}{r}0.840 \\
(0.237)\end{array}$ & $\begin{array}{r}1.60 \\
(0.475)\end{array}$ & $\begin{array}{r}0.825 \\
(0.227)\end{array}$ & $\begin{array}{r}1.74 \\
(0.454)\end{array}$ & $\begin{array}{r}1.80 \\
(0.456)\end{array}$ \\
\hline $50-$ Polls $_{t-1}$ & & & & $\begin{array}{r}0.032 \\
(0.045)\end{array}$ & & $\begin{array}{r}0.035 \\
(0.043)\end{array}$ & $\begin{array}{r}0.032 \\
(0.043)\end{array}$ \\
\hline $\begin{array}{l}\Delta \text { Polls }_{t} \times \\
\left(50-\text { Polls }_{t-1}\right)\end{array}$ & & & & $\begin{array}{l}-0.214 \\
(0.112)\end{array}$ & & $\begin{array}{l}-0.259 \\
(0.108)\end{array}$ & $\begin{array}{l}-0.262 \\
(0.108)\end{array}$ \\
\hline$\Delta$ Polls $_{\mathrm{t}-1}$ & & & & & $\begin{array}{r}0.845 \\
(0.228)\end{array}$ & $\begin{array}{r}0.910 \\
(0.227)\end{array}$ & $\begin{array}{r}1.43 \\
(0.455)\end{array}$ \\
\hline $\begin{array}{l}\Delta \text { Polls }_{t-1} \times \\
\left(50-\text { Polls }_{t-2}\right)\end{array}$ & & & & & & & $\begin{array}{l}-0.142 \\
(0.108)\end{array}$ \\
\hline June 26, 2013 & & $\begin{array}{r}6.73 \\
(1.12)\end{array}$ & $\begin{array}{r}6.72 \\
(1.10)\end{array}$ & $\begin{array}{r}6.68 \\
(1.09)\end{array}$ & $\begin{array}{r}6.62 \\
(1.05)\end{array}$ & $\begin{array}{r}6.57 \\
(1.04)\end{array}$ & $\begin{array}{r}6.61 \\
(1.04)\end{array}$ \\
\hline$r^{2}$ & 0.968 & 0.972 & 0.973 & 0.974 & 0.976 & 0.976 & 0.977 \\
\hline$\hat{\sigma}$ & 1.20 & 1.12 & 1.09 & 1.09 & 1.05 & 1.04 & 1.04 \\
\hline AIC & 87.7 & 55.8 & 46.0 & 45.8 & 27.4 & 24.8 & 25.0 \\
\hline $\mathrm{BIC}$ & 94.7 & 66.2 & 59.9 & 66.6 & 44.7 & 49.1 & 52.7 \\
\hline
\end{tabular}

Cell entries are least squares regression coefficients; standard errors in parentheses. $T=237$. The regressor 'Polls' is the model-based poll average discussed in the text; 'June 26, 2013' is a dummy variable for that day (Rudd's return as prime minister).

Note: Cell entries are least squares regression coefficients; standard errors in parentheses. $T=237$. The regressor 'Polls' is the model-based poll average discussed in the text; 'June 26, 2013' is a dummy variable for that day (Rudd's return as prime minister).

Source: Author's research. 
Regression analysis reported in Table 1 confirms that betting markets are quite responsive to an average of the polls, at least in 2013. The dependent variable in this analysis is the average of the Centrebet and Sportsbet ALP IPW, measured at 9 pm Sydney time each day, from 14 January 2013 until the election. The resulting series displays the random walk property observed in the analyses reported above, with the coefficient on the lagged dependent variable indistinguishable from one in all the models reported in Table 1. The large jump in ALP IPW associated with Rudd's return as prime minister on 26 June is captured with a dummy variable in models M2 through M7. Daily changes in the poll average generate betting market movements. Model M3 finds the effect of a 1 percentage point movement in ALP TPP produces a 'same day' change of about 0.84 points in ALP IPW, an effect roughly twice as large as the coefficients shown in Figure 4.

But this is only half the story. In model M4, change in the poll average is interacted with the lagged level of the poll average, differenced from 50 per cent ALP TPP. When Labor polls at levels suggesting a close election (say, 50 per cent TPP), a 1 percentage point change in the poll average has a large 'same day' effect, shifting ALP IPW by about 1.6 points. When Labor is polling poorly, say, at 44 per cent TPP, the betting markets pay little heed to a 1 percentage point movement: model M4 estimates the 'same day' effect in this case to be $1.60-0.214 \times 6=0.316$. This is entirely sensible. Movement in the poll average close to 50 per cent TPP ought to shape beliefs as to whether Labor will win the election more than the same movement at uncompetitive levels of TPP.

Models M5 through M7 indicate that the effects of changes in the polls on the betting markets are not instantaneous, but are absorbed over at least a two-day window, consistent with the considerable volatility in the betting markets on the day after polls are released presented in Figure 3. Model M6 repeats the interactive specification of M4, including the lagged change in the poll average, with model M7 interacting the lagged change with the second lag of the level of the poll average. ${ }^{12}$ Again, we see larger poll effects on ALP IPW when Labor is polling close to 50 per cent TPP. Using the estimates from model M7, a one-day, one-point rise/fall in the poll average starting from 50 per cent TPP would see ALP IPW rise/fall by 1.80 points today, and a further 1.43 points tomorrow, for a total, two-day, short-run effect of 3.23 points $(t=4.74)$. Note again that the random walk nature of the ALP IPW series means that these estimated effects are permanent. These short-run effects are much smaller when Labor is polling at uncompetitive levels; using the estimates from model M7, the same one-point change in the poll average-but starting from a baseline of 44 per cent ALP

12 The AIC model selection criterion points to M6 or M7 as the preferred models, although the BIC criterion - placing a higher premium on parsimony — suggests M5 (no interactions) as the preferred model. 
TPP — is estimated to produce a $1.80-0.262 \times 6=0.228$ point movement in ALP IPW today, and a further $1.43-0.142 \times 6=0.578$ point movement tomorrow; neither of these short-run changes are distinguishable from zero at conventional levels of statistical significance ( $t=0.67$ and 1.68, respectively), although the total short-run, two-day effect of 0.806 points on ALP IPW has $t=1.79$.

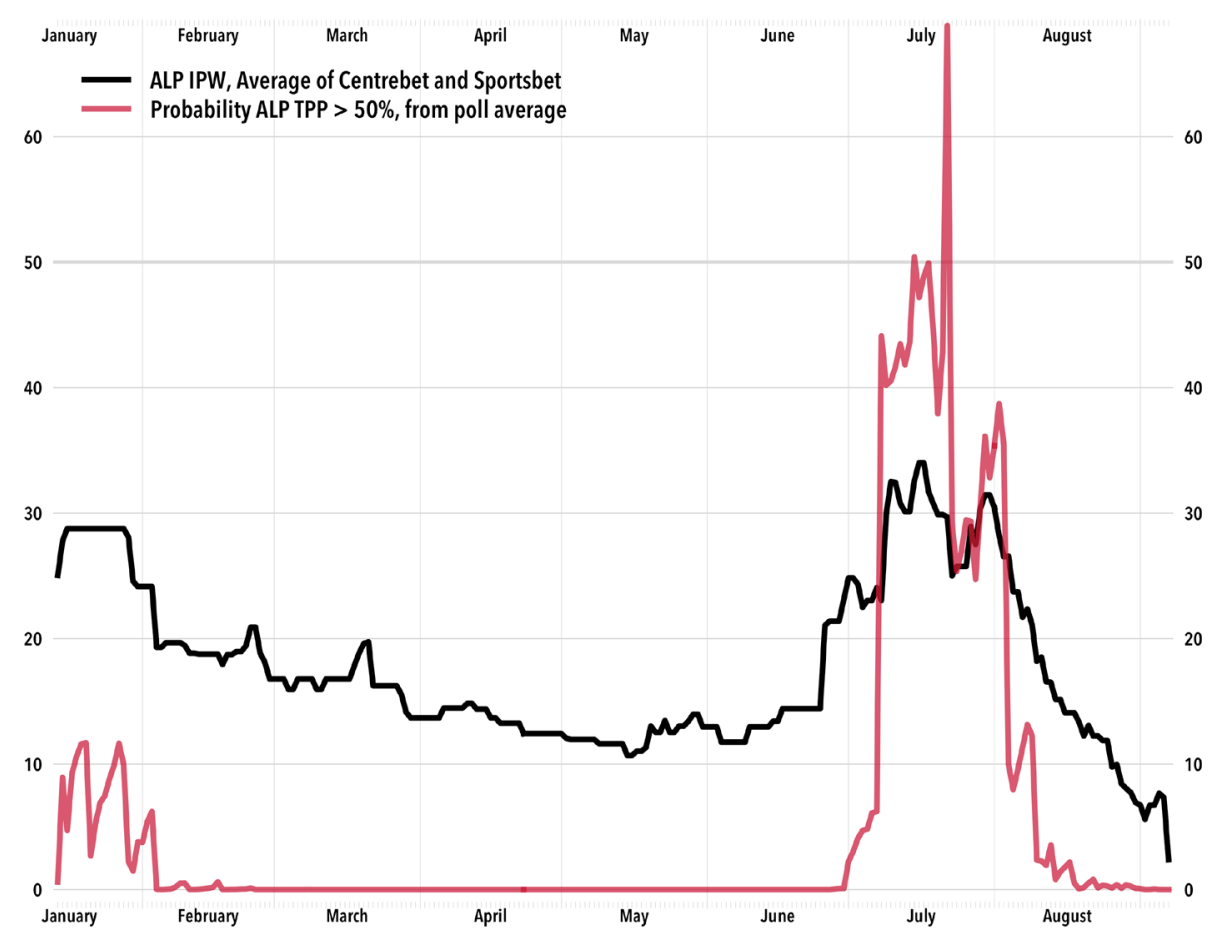

Figure 5: Daily time series, ALP IPW (average of Centrebet and Sportsbet, 9 pm Sydney time) and probability that ALP TPP exceeds 50 per cent based on poll average, 14 January 2013 to 7 September 2013

Source: Author's research.

Finally, in Figure 5, I compare two implied probabilities of Labor victory over 2013: the black line displays ALP IPW from an average of Centrebet and Sportsbet; the red line is the estimated probability that ALP TPP lies above 50 per cent, given the poll average used above (and uncertainty around the poll average on a given day). ${ }^{13}$ The markets always saw the Coalition as firm favourites. But with the exception of one or two days in July 2013, averaging the polls also generated the same conclusion, but with much greater confidence.

13 The 50 per cent TPP threshold probably results in an over-estimate of Labor's chances of winning; Labor probably needed a little more than 50 per cent TPP nationally to be able to form government. 
By late July the polls were again confidently indicating a Coalition win. The poll average IPW fell below 10 per cent in early August, some two to three weeks before the betting markets reached the same level of confidence. The polls appear to lead the betting markets in the 'race to the bottom' on the righthand side of Figure 5. By 10 August, the poll average IPW had fallen back to virtually zero, where it had been for most of 2013. Sportsbet conceded as much on 29 August, paying out its wagers on the Coalition.

\section{Conclusion}

Poll movements shape the betting markets, especially as the election draws close, and especially when the polls suggest the election might be closer than previously thought. Newspoll and Nielsen seem especially important 'market movers', probably due to their long-standing brand power and their association with newspapers in multiple media markets. Betting markets react quickly to changes in the polls, but not instantaneously. Poll movements take at least 48 hours to be digested by the betting markets, suggesting that secondary media reports of the polls are important (e.g. evening TV news reports of poll results from that morning's newspapers).

Polls and betting markets ask distinct questions: asking someone who they would vote for 'if an election were to be held this weekend' is not the same as asking who they think will win the next election. As the election draws closer, the hypothetical nature of the vote intention survey response fades. The betting markets pay more attention to the polls, particularly if the polls indicate the election is close. In a lop-sided election like 2013, we can expect that betting markets will react to little or no change in the polls, 'catching up' with the polls in the final week of the campaign. That is, we should not be surprised to see political betting markets reacting to polls. Rather, we should expect a somewhat subtle interplay between the two, as shown in the analyses I have presented here.

\section{References}

$A M$. 2012a. 'Nielsen poll encouraging for Govt, but Oppn well ahead'. Radio program transcript, ABC, Sydney, 27 August, viewed 28 January 2014: $<$ www.abc.net.au/am/content/2012/s3576302.htm >.

AM. 2012b. 'New polls give lift to ALP and Prime Minister'. Radio program transcript, ABC, Sydney, 17 September, viewed 28 January 2014: <www. abc.net.au/am/content/2012/s3591213.htm>. 
$A M$. 2012c. 'Opinion polls confirm lift for Labor and $\mathrm{PM}^{\prime}$. Radio program transcript, ABC, Sydney, 17 September, viewed 28 January 2014: <www. abc.net.au/am/content/2012/s3591293.htm>.

AM. 2013a. 'Parliamentary year kicks off with Cabinet reshuffle and poor polls for Labor'. Radio program transcript, ABC, Sydney, 4 February, viewed 28 January 2014: <www.abc.net.au/am/content/2013/s3682200.htm>.

AM. 2013b. 'Polling boost for Rudd on boats, but dips on PM preference'. Radio program transcript, ABC, Sydney, 23 July, viewed 28 January 2014: <www. abc.net.au/am/content/2013/s3808721.htm>.

Black, Simon. 2013. 'Opposition leader Tony Abbott sparks storm on Twitter after telling Bridie Jabour to "calm down"'. Daily Telegraph, 9 July, viewed 28 January 2014: <www.dailytelegraph.com.au/news/nsw/oppositionleader-tony-abbott-sparks-storm-on-twitter-after-telling-bridie-jabour-tocalm-down/story-fni0cx12-1226676460305>.

Conover, William J, Johnson, Mark E and Johnson, Myrle M. 1981. 'A comparative study of tests for homogeneity of variances, with applications to the outer continental shelf bidding data'. Technometrics 23: 351-61.

Jabour, Bridie. 2013. 'Tony Abbott denies wrongly claiming expenses from 2009 book tour'. Guardian Australia, 8 July, viewed 28 January 2014: <www. theguardian.com/world/2013/jul/08/tony-abbott-book-tour-expenses $>$.

Jackman, Simon. 2005. 'Pooling the Polls Over an Election Campaign'. Australian Journal of Political Science 40(4): 499-517.

Jackman, Simon. 2009. Bayesian Analysis for the Social Sciences. New York: Wiley.

Jackman, Simon. 2013a. 'Election 2013: betting markets suggest Labor will win just 50 seats'. Guardian Australia, 6 September, viewed 28 January 2014: $<$ www.theguardian.com/world/the-swing/2013/sep/06/election-2013betting-markets-suggest-labor-will-win-just-50-seats $>$.

Jackman, Simon. 2013b. 'Election 2013: average the averages and it looks like 1996'. Guardian Australia, 4 September, viewed 28 January 2014: <www. theguardian.com/world/the-swing/2013/sep/04/election-2013-pollinglike-1996>.

Kingston, Margo. 2013. 'EXCLUSIVE: Abbott forced to repay $\$ 9,400$ he charged taxpayers to promote his book'. No Fibs [blog], 6 July, viewed 24 February 2014: <nofibs.com.au/2013/07/06/exclusive-abbott-forced-to-repaytaxpayers-9400-he-charged-taxpayers-to-promote-his-book/>. 
Lateline. 2013. 'Rudd's popularity soars'. Television program transcript, ABC, Sydney, 9 July, viewed 28 January 2014: <www.abc.net.au/lateline/ content/2013/s3799592.htm>.

Leigh, Andrew and Wolfers, Justin. 2006. 'Competing Approaches to Forecasting Elections: Economic Models, Opinion Polling and Prediction Markets'. Economic Record 82(258): 325-40.

Maher, Sid. 2013. 'Election race still tight, Tony Abbott insists, despite Sportsbet payout'. Australian, 29 August, viewed 28 January 2014: <www. theaustralian.com.au/national-affairs/election-2013/election-race-still-tighttony-abbott-insists/story-fn9qr68y-1226706624356\#>.

PM. 2013. 'Rudd proposing radical changes to ALP rules'. Radio program transcript, ABC, Sydney, 8 July, viewed 28 January 2014: < www.abc.net.au/ pm/content/2013/s3798547.htm>.

Rhode, Paul W and Strumpf, Koleman. 2013. 'The Long History of Political Betting Markets: An International Perspective'. In Leighton Vaughan Williams and Donald S Siegel (eds), The Oxford Handbook of the Economics of Gambling, New York: Oxford University Press.

Wilson, Lauren. 2013. 'Abbott takes swipe at PM over expenses "dirt"'. The Australian, 10 July, viewed 28 January 2014: <www.theaustralian.com. $\mathrm{au} /$ national-affairs/abbott-takes-swipe-at-pm-over-expenses-dirt/storyfn59niix-1226676740115\#>.

Wolfers, Justin and Leigh, Andrew. 2002. 'Three Tools for Forecasting Federal Elections: Lessons from 2001'. Australian Journal of Political Science 37(2): 223-40.

Wolfers, Justin and Zitzewitz, Eric. 2004. 'Prediction Markets'. Journal of Economic Perspectives 18(2): 107-26.

Wolfers, Justin and Zitzewitz, Eric. 2006. 'Interpreting prediction market prices as probabilities'. NBER Working Paper No. 12200, National Bureau of Economic Research, May, viewed 28 January 2014: <www.nber.org/papers/ w12200>. 
This text taken from Abbott's Gambit: The 2013 Australian Federal Election, edited by Carol Johnson and John Wanna, published 2015 by ANU Press, The Australian National University, Canberra, Australia. 